\title{
Evaluation of long-term law enforcement monitoring in a West African protected area
}

\author{
Jerry Owusu Afriyie, Michael O. Asare \\ Jones Osei-Mensah and Pavla HejCmanová
}

\begin{abstract}
Law enforcement in protected areas is critical for ensuring long-term conservation and achieving conservation objectives. In 2004, patrol-based monitoring of law enforcement was implemented in protected areas in Ghana. Here, we evaluate long-term trends and changes in patrol staff performance, and illegal activities, in the Kogyae Strict Nature Reserve. The assessment was based on ranger patrol-based monitoring data collected during January 2006August 2017. Along the patrol routes, patrol officers recorded all encounters with illegal activities associated with hunting and capturing or harming of animals. Across all years, staff performance was lowest in 2006 as staff learned the system but increased in 2007 and peaked in 2010, the latter as a result of motivation of the patrol staff. After 2011, staff performance decreased, mainly because of the retirement of some patrol staff and insufficient logistical support for successful patrolling. Snares were the most commonly recorded indicators of illegal activity. Because their use is silent, poachers using snares are less likely to be detected than poachers using other forms of hunting. Long-term assessment of patrolbased monitoring data provides reliable information on illegal activities related to wildlife, to enable stakeholders to design effective measures for biodiversity conservation. Our assessment indicates that patrol staff performance in Kogyae is, at least partly, dependent on governmental or external support and incentives, in particular the provision of equipment and transport facilities.
\end{abstract}

Keywords Ghana, illegal wildlife hunting, monitoring and assessment, patrol staff performance, West Africa, wildlife conservation

\section{Introduction}

Tlegal activities such as poaching, livestock grazing, and extraction of timber and non-timber forest products are the major threats to biodiversity in protected areas

Jerry Owusu Afriyie and Pavla Hejcmanová (Corresponding author, (1) orcid. org/0000-0001-9547-4302) Faculty of Tropical AgriSciences, Czech University of Life Sciences Prague, Kamýcká 129, Prague 6-Suchdol CZ 165 00, Czech Republic. E-mail hejcmanova@ftz.czu.cz

Michael O. Asare Faculty of Environmental Science, Czech University of Life Sciences Prague, Prague, Czech Republic

Jones Osei-Mensah Wildlife Division of the Forestry Commission, Accra, Ghana

Received 9 August 2019. Revision requested 13 September 2019.

Accepted 25 March 2020. First published online 18 May 2021.
(Hilborn et al., 2006; Biggs et al., 2013). The conservation objectives of protected areas in West Africa mostly include the protection of animal populations against commercial or non-commercial subsistence harvesting and protection of ecosystems against the extraction of timber and other resources, to prevent habitat loss. Efforts are needed to achieve these objectives because of the increasing human population of West Africa (International Cooperation and Development, 2016) and, consequently, increasing socioeconomic pressures on land and resources. Management of protected areas therefore requires comprehensive approaches involving a clearly defined vision, mission and management plan, effective law enforcement, training programmes for staff, educational and awareness campaigns, and cooperation with local communities. Effective law enforcement in protected areas results in fewer illegal activities (Fischer et al., 2014; Moore et al., 2017) but, when not implemented, biodiversity may decline (Peres \& Terborgh, 1995).

Assessing law enforcement effectiveness in protected areas in Africa relies mostly on ranger-collected monitoring data. The effectiveness of law enforcement depends on patrol strategies, determined by managers, and on the structure of enforcement incentives (Robinson \& Lokina, 2012). The deterrence of illegal activities could, however, be low if detection rates are low and benefits outweigh penalties, and even lower if there is an ambiguous legal framework regarding land tenure (e.g. Abbot \& Mace, 1999; Nolte, 2016).

Optimal ranger patrol strategies differ depending on the threat. Each threat may be targeted effectively based on the knowledge of past spatial and temporal patterns of illegal activities and an appropriate allocation of ranger patrols (Critchlow et al., 2015). Strategies targeting illegal activities based on predictions of their spatial distribution improve law enforcement efficiency even without any increase in ranger resources (Nyirenda \& Chomba, 2012; Plumptre et al., 2014; Critchlow et al., 2017). Approaches using spatial planning tools make law enforcement more effective, yet are not applied in all protected areas, especially in West Africa. The main reasons seem to be inadequate training in the use of software and the lack of evaluation of outcomes from ranger patrols.

In Ghana, a ranger-based monitoring system was implemented by the Wildlife Division of the Forestry Commission in 2004. It focuses on patrols assigned to monitor illegal activities and mammal populations in protected areas. The system incorporated tools to assess staff performance and the effectiveness of field operations, to assist protected area managers in adopting appropriate law 
enforcement strategies to achieve conservation objectives (Jachmann, 2008a,b). This system was evaluated by several studies that identified internal (e.g. budget) and external (e.g. local population density, level of tourism) factors as key elements that may support or decrease the performance of protected areas (Jachmann, 2008a,b; Jachmann et al., 2011; Wiafe \& Amoah, 2012; Wiafe, 2016). These studies focused on short-term data (2-4 years) collected shortly after the implementation of the system. The long-term dynamics of the system have not previously been examined.

The aim of our investigation was therefore to examine the long-term dynamics of the conventional ranger-based monitoring system in the Kogyae Strict Nature Reserve in Ghana and to provide an assessment of the incidences of poaching activities. Using data for January 2006-August 2017 on monthly patrol performance and poaching-related encounters, our objectives were to evaluate the temporal pattern of patrol staff performance and to examine what factors or events could have affected it. In addition, we investigated the temporal patterns of illegal activities in the Reserve and aimed to identify whether the increasing human population around the Reserve affects the encounter rate of illegal activities.

\section{Study area}

The $386 \mathrm{~km}^{2}$ Kogyae Strict Nature Reserve (Fig. 1) lies in the Afram Plains region of Ghana. It is a flat area with a mean altitude of $120 \mathrm{~m}$, with some areas reaching $230 \mathrm{~m}$. The higher areas are the watershed for a network of streams dominated by tributaries of the Afram and Sene rivers, most of which dry up in the dry season (Hagan, 1998). The climate has dry (November-March) and wet (April-October) seasons, with a total annual rainfall of $1,200-1,300 \mathrm{~mm}$. Kogyae lies between transitional woodland (semi-deciduous forest) and Guinea savannah woodland and open grasslands (Wildlife Department, 1994). A large ungulate community of conservation importance includes the buffalo Syncerus caffer, hartebeest Alcelaphus buselaphus, waterbuck Kobus ellipsiprymnus, Buffon's kob Kobus kob, bushbuck Tragelaphus scriptus, oribi Ourebia ourebi, red-flanked Cephalophus rufilatus, black Cephalophus niger, Maxwell's Cephalophus maxwelli and bay Cephalophus dorsalis duikers, red river hog Potamochoerus porcus and warthog Phacochoerus africanus. The Reserve also supports the baboon Papio anubis, patas Erythrocebus patas, green Chlorocebus sabaeus, mona Cercopithecus mona and spot-nosed Cercopithecus petaurista monkeys, and white-thighed colobus Colobus vellerosus (Wildlife Department, 1994).

The Kogyae Strict Nature Reserve is the extended former Kujani Forest Reserve, formerly managed by the Forestry Department. In 1971, the administration of the Reserve was handed to the Wildlife Division for strict protection

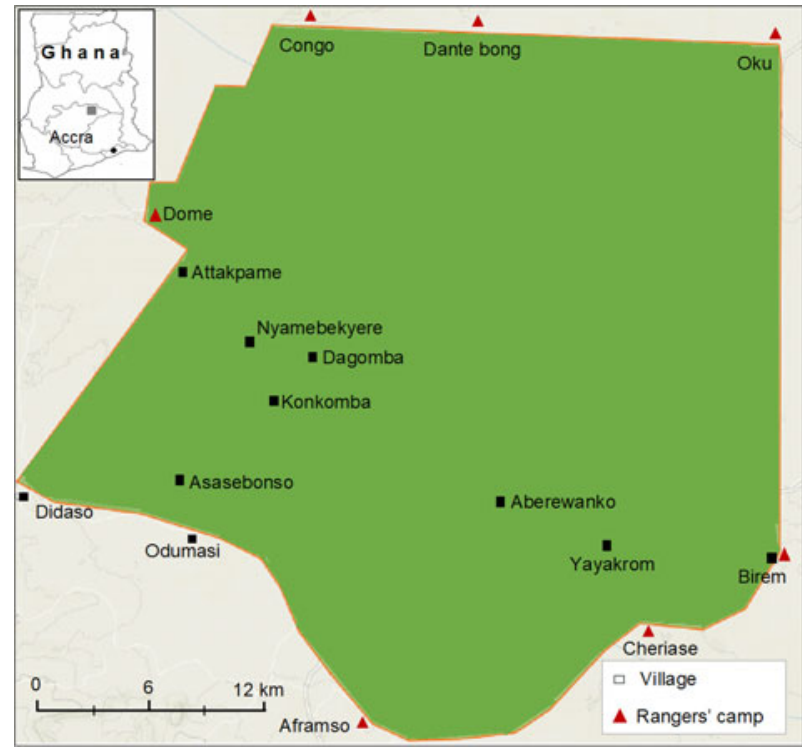

Fig. 1 Kogyae Strict Nature Reserve in Ghana, indicating the location of villages and rangers' camps (adapted from Ayivor \& Ntiamoa-Baidu, 2015).

under the Wildlife Reserve Regulations, LI 710. The Kujani Forest Reserve boundary extension was to obtain a viable ecological unit for the Kogyae Strict Nature Reserve (Oduro-Ofori et al., 2015). This became necessary because studies by the Wildlife Division indicated that, in the dry season, the animals in the Reserve depend on the rivers in unprotected areas for survival (Ayivor \& Ntiamoa-Baidu, 2015). The extension also includes the communities of Asasebonso, Atakpame, Nyamekyere Dagomba, Birem, Yahayakura, Aberewanko and Konkomba. Additionally, Aframso, Birem, Chichibon and Kyeiase lie along the border of the Reserve (Ayivor \& Ntiamoa-Baidu, 2015). Local communities comprise predominantly farmers, with up to $75 \%$ of the people in the area working in the agriculture sector (Ministry of Finance, 2015). Farming practices involve a slash and burn method of land clearing and cultivation of a variety of crops (yam, maize, paddy rice, groundnuts, cassava, cowpeas and vegetables). Fifteen and $10 \%$ of the population work in the industry and service sectors, respectively. The population in the district is increasing at a rate of $1.4 \%$ per year (Ministry of Finance, 2015).

The Kogyae Strict Nature Reserve is managed by a manager, who is assisted by a law enforcement officer in charge of field operations. The patrol staff are employees of the Wildlife Division and are based only in Kogyae. The number of patrol staff varied from 31 to 44 during 2006-2017. The annual budget during 2006-2015 was GHC 6,000 (c. 1,130 USD); this was increased to GHC 40,000 (c. 7,460 USD) in 2016.

Kogyae has four management zones: the Protected, Special-use, Restoration and Development Zones. The Protected Zone is the largest, comprising $220 \mathrm{~km}^{2}$ (57\%). This is the most important and least disturbed Zone, fully 
dedicated to conservation. The $79 \mathrm{~km}^{2}$ Special-use Zone $(20 \%)$ is an area where some farming activities by local inhabitants are allowed, but not hunting or logging. The $86 \mathrm{~km}^{2}$ Restoration Zone (22\%) are those lands that have been degraded or significantly altered by farming, logging and charcoal making; they are leased to immigrants for settlement and farming. The management priorities in this Zone exclude all forms of destructive activities and the Zone is dedicated to the recovery of vegetation and wild animal populations. The $1 \mathrm{~km}^{2}$ Development Zone (1\%) has been set aside for staff accommodation, administration facilities, a research station and a centre for conservation education.

\section{Methods}

\section{Patrol operations management}

Kogyae uses conventional law enforcement in the form of foot patrols that operate from the headquarters and from camps established in each of seven communities at the periphery of the Reserve. A grid map is used for planning of patrol routes, to ensure that the entire Reserve is patrolled each month (described in detail by Jachmann, 2008a). A foot patrol comprises at least five rangers, led by the most senior of the group. Standardized forms are used to record data: the number of staff on patrol, duration, total distance travelled, and types, number and locations of illegal activity encountered. Illegal activities recorded include poachers arrested, poachers observed, firearms confiscated, gunshots heard, poachers' camps found, animals found killed, snares recovered and cartridges found.

\section{Evaluation of patrol staff performance}

In evaluating the performance of patrol staff, we used the monthly distance walked by all patrols and the effective patrol time, which is a measure of time spent in the field by a patrol team without including deployment time (sensu Bell, 1985, as applied by Jachmann, 2008a; Nyirenda \& Chomba, 2012). To facilitate comparison of law enforcement performance across protected areas, two standardized measures of monthly patrolling effort were used: (1) effective patrol man-days calculated as the monthly effective patrol time divided by 8 hours (assigned time unit as standard for 1 patrol day), multiplied by the number of staff in the patrol group, and (2) effective patrol days calculated as the total effective patrol man-days for the month divided by the number of active staff on duty for the month.

We used catch per unit effort (Bell, 1985; Jachmann, 2008a) to measure the level of encounter rates with indicators of illegal activities per given period. Catch refers to the total number of monthly encounters with indicators of illegal activity, and the effort is the total number of effective patrol man-days per month.

A kilometric index of abundance, which is the ratio of the number of illegal activities encountered to distance walked by patrols per month, was used as a second measure of encounter rate. The kilometric index of abundance was multiplied by 100, to give the number of encounters per $100 \mathrm{~km}$.

\section{Data collection and analyses}

We collected data on law enforcement operations during January 2006-August 2017, and we carried out field visits and informal interviews with the manager and patrol staff to gain insights into patrol operations. Locations of the illegal activities encountered were not available and therefore spatial aspects of law enforcement could not be evaluated. Total distance walked by patrols was only available for 2006-2014, when the GPS units were functioning. All data parameters recorded were examined with the KolmogorovSmirnov test and found to be normally distributed.

To examine any annual, monthly or seasonal (wet vs dry) trends in patrol staff performance, general linear models were applied for each parameter separately as the dependent variable, with year, month and season as the independent predictors. In the case of significant differences, we used post hoc Tukey HSD tests to examine any further differences.

Catch per unit effort and the kilometric index of abundance were highly correlated (Pearson's $r=0.94, \mathrm{P}<0.001$ ) and therefore only the catch per unit effort was used for further analyses. To examine differences in encounter rates with various types of illegal activities and their temporal trends, we used general linear models, with catch per unit effort as the dependent variable and year, month, illegal activity type, year $\times$ illegal activity type and month $\times$ illegal activity type interactions as the independent predictors. Post hoc Tukey HSD tests were used to examine any further differences among the levels of predictors if the general linear model was significant. To examine the effect of patrol staff performance and the number of inhabitants in the district surrounding Kogyae (which increased annually during the years of monitoring) on encounter rate with illegal activities, we used simple linear regression. We used STATISTICA 13 (TIBCO Software, Palo Alto, USA) to perform all statistical analyses.

\section{Results}

\section{Patrol staff performance}

The mean monthly distance walked by patrols in the Kogyae Strict Nature Reserve during 2006-2014 was 1,221 \pm SE 47 $\mathrm{km} / \mathrm{month}$, with a minimum of $623 \pm \mathrm{SE}$ o $\mathrm{km} / \mathrm{month}$ in 2012 to a maximum of $1,874 \pm$ SE $64 \mathrm{~km} / \mathrm{month}$ in 2010 . Mean monthly effective patrol days were $17.5 \pm$ SE 0.3 and 

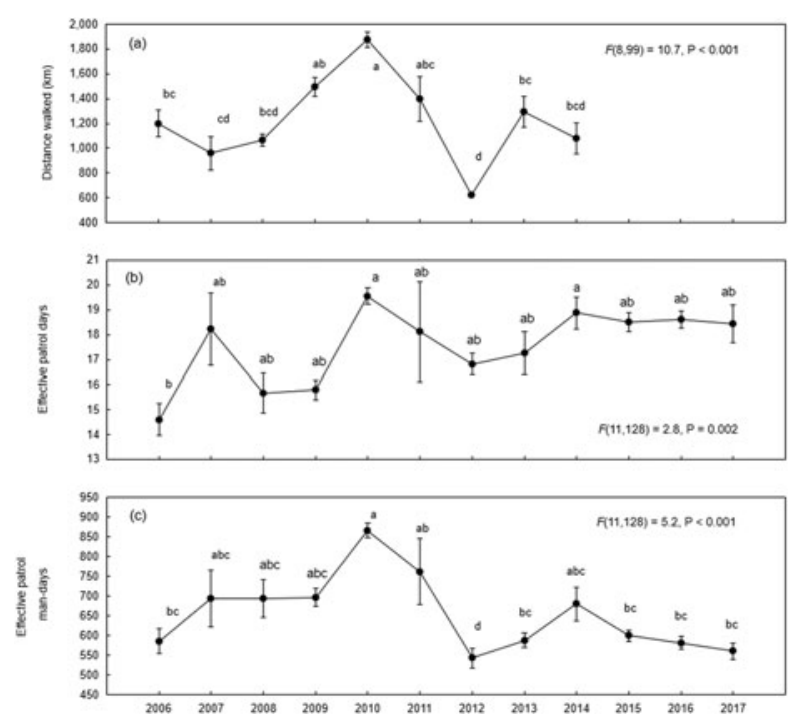

FIG. 2 Patrol staff performance in the Kogyae Strict Nature Reserve, Ghana (Fig. 1), during 2006-2017 measured as (a) mean monthly patrol distance walked, (b) mean monthly effective patrol days, and (c) mean monthly effective patrol man-days. Bars indicate SE. Different letters for years indicate significant differences at $\mathrm{P}=0.05$, detected with Tukey HSD post hoc tests.

mean monthly effective patrol man-days were $657 \pm$ SE 14 during 2006-2017. The dynamics of patrol staff performance differed significantly among years but there was no obvious trend (Fig. 2). Performance in 2006 was similar to the levels measured after 2014 in all three parameters, with peaks in 2010 (Fig. 2).

Differences in the monthly distance walked by patrols (Fig. 3a) and effective patrol days (Fig. 3b) were not significant. Effective patrol man-days were, however, significantly different, with a peak in March and a low in October (Fig. 3c), and higher in the dry (686 \pm SE 18 patrol mandays) than in the wet season (628 \pm SE 21 patrol man-days Fig. 3c).

\section{Illegal activities}

There were differences in the mean encounter rates of illegal activities during 2006-2017 $(F(6,947)=52.5, \mathrm{P}<0.001)$. The highest encounter rate was with snares, followed by gunshots heard. The lowest indices were confiscated firearms and poachers arrested (Table 1).

There were annual increases in illegal activities encountered (comprising principally numbers of snares found, poachers observed and gunshots heard) following the implementation of ranger-based monitoring in 2004, to a peak catch per unit effort in 2009 (Fig. 4). Illegal activities then fell and remained relatively constant during 20122017. There was no significant variation in catch per unit effort of illegal activities between months (Fig. 5).
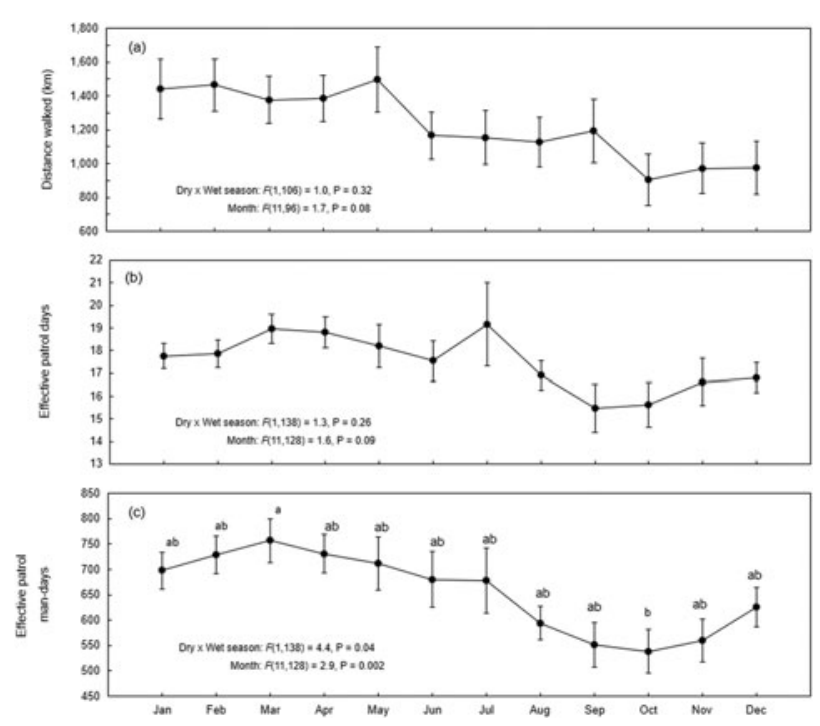

FIG. 3 Monthly patrol staff performance in the Kogyae Strict Nature Reserve, Ghana measured as (a) mean patrol distance walked, (b) mean effective patrol days, and (c) mean effective patrol man-days. Bars indicate SE. Different letters indicate significant differences at $\mathrm{P}=0.05$, detected with Tukey HSD post hoc tests. The dry season is November-March and the wet season April-October.

Encounter rates of illegal activities decreased with increased effective patrol days $\left(r^{2}=0.05, \mathrm{P}=0.008\right)$. Similarly, the encounter rates with illegal activities showed a significantly negative relationship with the increasing number of inhabitants in the district where Kogyae Strict Nature Reserve is located $\left(r^{2}=0.1, \mathrm{P}<0.001\right)$.

\section{Discussion}

\section{Patrol staff performance}

The performance of patrol staff in Kogyae was lowest in 2006, most likely because the patrol-based monitoring system was then in the early phase of its implementation. Analysis of staff performance in the first 2 years (20052006) after the implementation of the patrol-based monitoring system in nine protected areas in Ghana (Jachmann, 2008a) revealed that performance of staff in Kogyae was 3.8-16.3 effective patrol days, similar to that of Ankasa Conservation Area (3.4-14.8 effective patrol days). Our study shows that patrol staff performance in Kogyae improved by c. $35 \%$ in 2007 (Fig. 2b), and was highest in 2010, primarily a result of motivation of rangers through external support from the Royal Netherlands Embassy in Accra in the form of food rations (J. Osei-Mensah, pers. comm., 2018). The findings of Jachmann's analysis (2008a) aroused the interest of the management of the Ghanaian Wildlife Division in the patrol system, and motivations were offered across protected areas in Ghana (Jachmann, 2008a). 
TABLE 1 Mean \pm SE catch per unit effort and kilometric index of abundance of illegal activities encountered in the Kogyae Strict Nature Reserve (Fig. 1) during 2006-2017.

\begin{tabular}{|c|c|c|}
\hline Illegal activity & Mean \pm SE catch per unit effort ${ }^{1}$ & $\begin{array}{l}\text { Mean } \pm \text { SE kilometric index } \\
\text { of abundance } \times 100^{2}\end{array}$ \\
\hline Poachers arrested & $0.0011^{\mathrm{a}} \pm 0.0002$ & $0.063 \pm 0.011$ \\
\hline Poachers observed & $0.0037^{\mathrm{b}} \pm 0.0005$ & $0.226 \pm 0.033$ \\
\hline Poachers' camps found & $0.0017^{\mathrm{ab}} \pm 0.0002$ & $0.113 \pm 0.012$ \\
\hline Gunshots heard & $0.0080^{c} \pm 0.0007$ & $0.454 \pm 0.049$ \\
\hline Firearms confiscated & $0.0011^{\mathrm{a}} \pm 0.0002$ & $0.057 \pm 0.013$ \\
\hline Snares found & $0.0113^{\mathrm{d}} \pm 0.0013$ & $0.698 \pm 0.088$ \\
\hline Animals found killed & $0.0015^{\mathrm{ab}} \pm 0.0002$ & $0.092 \pm 0.014$ \\
\hline Cartridges found & $0.0025^{\mathrm{ab}} \pm 0.0008$ & $0.171 \pm 0.071$ \\
\hline
\end{tabular}

${ }^{1}$ Using Tukey HSD post hoc tests, mean values with different letters indicate significant difference $($ at $\mathrm{P}=0.05)$ among the encounters of illegal activities during 2006-2017.

${ }^{2}$ Number of observations per $100 \mathrm{~km}$.

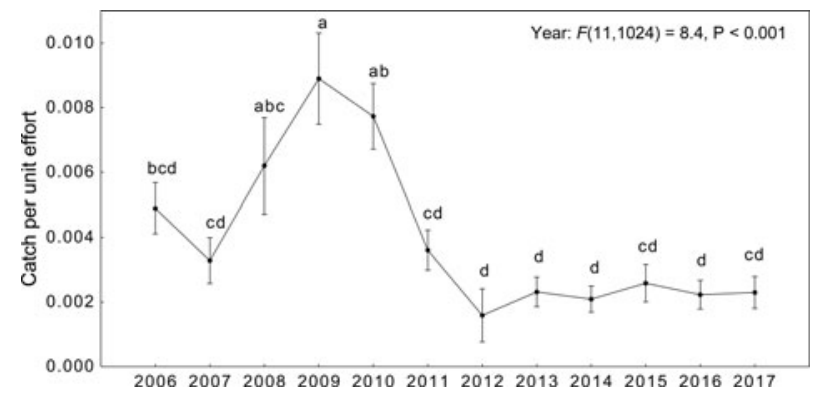

FIG. 4 Inter-annual trend trends of encounter rates $( \pm$ SE) with illegal activities per monthly effective patrol man-days in the Kogyae Strict Nature Reserve during 2006-2017. Different letters indicate significant differences at $\mathrm{P}=0.05$, detected by Tukey HSD post hoc tests.

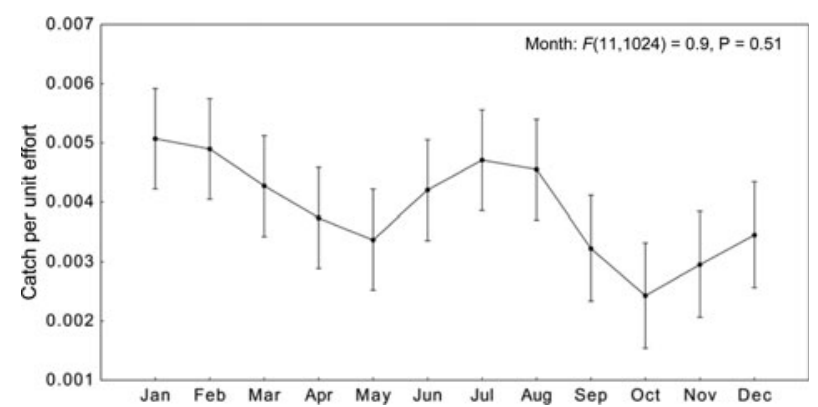

FIG. 5 Mean encounter rates $( \pm S E)$ of illegal activities from January to December in the Kogyae Strict Nature Reserve across all years (2006-2017).

The reasons for the decline in staff performance after 2011 were threefold. Firstly, in 2011 and 2012 a number of the patrol staff retired, and there was a delay in the recruitment of new staff. Secondly, long patrols mostly accounted for the high performance of patrol staff, and for each such patrol, the Reserve vehicle transported patrol staff and equipment to the locations where patrols began. However, the vehicle was stolen in 2012 and thereafter patrol staff resorted to long patrols on foot, which is time- and energyconsuming, especially when moving between the base and the locations where patrols started and finished. Thirdly, the tents required for long patrols were damaged, and replacements were not provided. All these factors caused patrol staff to resort to day or night patrols only. Provision of equipment is particularly crucial given the dangerous nature of the work, with poachers sometimes resisting arrest violently, and in some cases injuring or even killing patrol staff (in Kyabobo National Park: Frimpong, 2013; in Mole National Park: Daily Graphic, 2018). Poachers have killed or assaulted patrol staff in Lobéké National Park, Cameroon (Mathiesen, 2016), Maswa Game Reserve, Tanzania (BBC News, 2016) and Savé Valley Conservancy, Zimbabwe (Lindsey et al., 2011).

Unofficial reports suggest patrol staff performance decreases during the wet season in Ghana because the patrol staff tend their own farms during this season, to supplement their income (Wiafe \& Amoah, 2012). However, we did not record any significant difference in the performance of staff between the dry and wet seasons, similar to the report by Wiafe \& Amoah (2012) for the Kakum Conservation Area in Ghana. However, during the months of the peak wet season, patrol staff performance was slightly but not significantly lower compared to the dry season (Fig. 3). This was probably because of intensive rainfall, which makes movement and sightings difficult, and because there was no logistical support specific for rainy weather.

\section{Changes in the encounters of illegal activities}

In 2008 and 2009 patrol staff performance slightly decreased, though not significantly, in comparison with that of 2007 (Fig. 2), but an increase was observed in encounter rates with illegal activities (Fig. 4). This could have been the 
result of patrol staff concentrating their operations in areas where there was a high probability of encountering illegal activity, especially in the Special-use Zone. Although patrol staff effort was greatest in 2010 there was a lower encounter rate of illegal activities compared to the highest encounter rates in 2009. Poachers may have adjusted their behaviour (Montgomery \& Blalock, 2010) or ceased to operate upon noticing the increase in regular patrols, decreasing the likelihood of illegal activities being detected. During 2011-2017, when patrol staff performance stabilized (Fig. 2), the detection of illegal activities remained low (Fig. 4). This could be attributed to patrol staff learning and gaining experience in adapting their patrol strategies to achieve patrol objectives, as suggested by the Park manager (J. Osei-Mensah, pers. comm., 2018). Another possible explanation is that poachers changed their behaviour, leading to a decrease in the rate of detection by patrols even in high-risk areas (as reported by Abbot \& Mace, 1999), and/or changed their poaching techniques.

The most frequently recorded illegal activity in Kogyae was the use of snares, as in other protected areas in Ghana (Wiafe, 2018) and elsewhere (Queen Elizabeth Conservation Area, Uganda: Critchlow et al., 2015; Serengeti National Park, Tanzania: Hurt \& Ravn, 2000; Nyahongo et al., 2005; Holmern et al., 2007). As the use of snares is silent, poachers using them are less likely to be detected than poachers using firearms, and placing more snares maximizes the probability of hunting success. Animals found dead during patrols had mostly been caught in snares, similar to reports from other countries (e.g. Zambia: Becker et al., 2013), or died of infections from injuries suffered as a result of trying to escape from snares. The apparent preference for snares by poachers in Kogyae suggests that snaring may lead to a lower arrest rate because the time spent hunting is reduced (Table 1 ). This change in poaching method from firearms to snares was indicated by the changes in the encounter rates of poachers observed, which was notably high in 2008 and 2009 (Fig. 5). After 2009, a decline was observed in the direct encounters and in the numbers of poacher camps found in the Reserve, gunshots heard, and firearms confiscated. 'Cartridges found' was included as a new category of illegal activity in Kogyae in 2013 but was not frequently encountered by patrol teams.

The weak relationship between the encounters with illegal activities and the number of people in the district where Kogyae is located contrasts with the general findings of increasing pressures on ecosystems coupled with increasing population (e.g. Veldhuis et al., 2019). The weakness of this relationship in Kogyae might be a consequence of the implementation of regular and active patrols specifically in the Reserve, because many inhabitants of the local communities, upon noticing these patrols, avoided entry into the Reserve (J. Osei-Mensah, pers. comm., 2018). However, data on encounters of illegal activities are directly related to the killing of animals, whereas other human activities, such as conversion of habitat for agricultural purposes or grazing of livestock within the Reserve, were not covered in the ranger-based patrol monitoring system. Including these aspects as illegal activities could render the monitoring and evaluation both difficult and controversial as agricultural land use is part of the livelihoods of people inhabiting the Special-use Zone. Considering that the majority of the population is involved in agricultural production, the effects of these activities on wildlife and their habitats throughout the Reserve require further study.

Long-term assessment of law enforcement in protected areas provides stakeholders with information on patrol staff performance over time and on illegal activities related to wildlife. Our findings indicate that patrol staff performance in Kogyae Strict Nature Reserve was partly dependent on logistical support, such as the provision of GPS units, tents, motorbikes, bicycles and other equipment. It means that patrol staff performance depends on the budget allocated by the government to protected areas or on external funding to support conservation. Improvements in provision of equipment would serve not only as an incentive for working in uncomfortable conditions but would also help rangers to feel their work is valued. To improve law enforcement and conservation in Kogyae, we also recommend training for rangers in the use of monitoring tools based on spatial information and the implementation of law enforcement allocation methods that allow prediction of illegal activities and targeting of conservation priorities. Spatial crime mapping approaches such as the Management Information SysTem (MIST, 2021) and the Spatial Monitoring and Reporting Tool (SMART, 2021) have proven to be effective in resource-limited settings (e.g. Critchlow et al., 2017), but this approach has not been used in Kogyae. These spatio-temporal approaches, which link the occupancy of large mammals to habitats and to human-related factors, would enable decision-makers to act more efficiently for successful conservation.

Acknowledgements The study was supported by the Czech University of Life Sciences Prague, project CIGA 20185007. We thank the Wildlife Division of Ghana for granting permission for this study, and the rangers in Kogyae Strict Nature Reserve, including at the headquarters, for their support.

Author contributions Conceptualization, design: JOA, MOA; data collection, analysis, interpretation: all authors; writing, revision: JOA, MOA, PH.

\section{Conflicts of interest None.}

Ethical standards Research approval and permits were granted by the Wildlife Division of the Forestry Commission of Ghana (permit number WD/A.30/VOL. 11/28). This research abided by the Oryx guidelines on ethical standards. 


\section{References}

Аввот, J.I.O. \& MAсе, R. (1999) Managing protected woodlands: fuelwood collection and law enforcement in Lake Malawi National Park. Conservation Biology, 13, 418-421.

Ayivor, J.S. \& NTIAmoa-Baidu, Y. (2015) Assessing the socio-economic stressors of Ghana's only Strict Nature Reserve: Kogyae. Parks, 21.2, 85-100.

BBC News (2016) Tanzania Elephant Poachers Kill British Helicopter Pilot. bbc.com/news/uk-3545049o [accessed 26 November 2018].

Becker, M., McRobb, R., Watson, F., Droge, E., Kanyembo, B., Murdoch, J. \& KaKumbi, C. (2013) Evaluating wire-snare poaching trends and the impacts of by-catch on elephants and large carnivores. Biological Conservation, 158, 26-36.

BELL, R.H.V. (1985) Monitoring of illegal activity and law enforcement in African conservation areas. In Conservation and Wildlife Management in Africa (eds R.H.V. Bell \& E. McShane-Caluzi), pp. 317-351. US Peace Corps, Washington, DC, USA.

Biggs, D., Courchamp, F., Martin, R. \& Possingham, H.P. (2013) Conservation. Legal trade of Africa's rhino horns. Science, 339, 1038-1039.

Critchlow, R., Plumptre, A.J., Alidria, B., Nsubuga, M., Driciru, M., Rwetsiba, A. et al. (2017) Improving lawenforcement effectiveness and efficiency in protected areas using ranger-collected monitoring data. Conservation Letters, 10, 572-58.

Critchlow, R., Plumptre, A.J., Driciru, M., Rwetsiba, A., Stokes, E.J., Tumwesigye, C. et al. (2015) Spatiotemporal trends of illegal activities from ranger-collected data in a Ugandan national park. Conservation Biology, 29, 1458-147.

Daily Graphic (2018) Poachers kill Mole National Park wildlife officer. Daily Graphic, 25 March 2018. graphic.com.gh/news/ general-news/poachers-kill-mole-national-park-wildlife-officer. html [accessed 25 March 2018].

Fischer, A., Naiman, L.C., Lowassa, A., Randall, D. \& Rentsch, D. (2014) Explanatory factors for household involvement in illegal bushmeat hunting around Serengeti, Tanzania. Journal of Nature Conservation, 22, 491-496.

FRIMPONG, E.A. (2013) 62 forest guards killed in 2 years by illegal miners, chainsaw operators, and wildlife poachers. Daily Graphic, 30 April 2013. graphic.com.gh/news/general-news/62-forest-guardskilled-in-2years-by-illegal-miners-chainsaw-operators-andwildlife-poachers.html [accessed 30 April 2018].

Hagan, J.E. (1998) The Kogyae Strict Nature Reserve. The World Bank/WBI's CBNRM Initiative. GIMPA, Accra, Ghana.

Hilborn, R., Arcese, P., Borner, M., Hando, J., Hopcraft, G., Lогвоокі, M. et al. (2006) Effective enforcement in a conservation area. Science, 314, 1266.

Holmern, T., Muya, J. \& Røskaft, E. (2007) Local law enforcement and illegal bushmeat hunting outside the Serengeti National Park, Tanzania. Environmental Conservation, 34, 55-63.

HURT, R. \& RAVN, P. (2000) Hunting and its benefits: an overview of hunting in Africa with special reference to Tanzania. In Wildlife Conservation by Sustainable Use (eds H.H.T. Prins, J.G. Grootenhuis \& T.T. Dolan), pp. 295-314. Kluwer Academic Publishers, Boston, USA.

International Cooperation and Development (2016) Larger than Elephants: Inputs for an EU Strategic Approach to Wildlife Conservation in Africa-Regional Analysis. European Commission, Brussels, Belgium.

JaChmann, H. (2008a) Monitoring law-enforcement performance in nine protected areas in Ghana. Biological Conservation, 141, 89-99.

JACHMANN, H. (2008b) Illegal wildlife use and protected area management in Ghana. Biological Conservation, 141, 1906-1918.

Jachmann, H., Blanc, J., Nateg, C., Balangtaa, C., Debrah, E., Damma, F. et al. (2011) Protected area performance and tourism in Ghana. South African Journal of Wildlife Research, 41, 95-109.

Lindsey, P.A., Romañach, S.S., Matema, S., Matema, C., Mupamhadzi, I. \& Muvengwi, J. (2011) Dynamics and underlying causes of the illegal bush meat trade in Zimbabwe. Oryx, 45, 84-95.

Mathiesen, K. (2016) Cameroonian ranger killed by wildlife poachers. The Guardian, 10 December 2016. theguardian.com/ environment/2016/dec/10/cameroonian-ranger-killed-wildlifepoachers [accessed 10 March 2020].

Ministry of Finance (2015) The Composite Budget of the Sekyere Central District Assembly for the 2016 Fiscal Year. Ministry of Finance, Accra, Ghana. mofep.gov.gh/sites/default/files/compositebudget/2016/AR/Sekyere-Central.pdf [accessed 7 May 2020].

Mist (Management Information SysTem) (2021) ecostats.com/ MIST [accessed 11 January 2021].

Montgomery, R. \& Blalock, M.G. (2010) The impact of access, cost, demographics, and individual constraints, on hunting frequency and future participation. Academy of Marketing Studies Journal, $14,15-131$.

Moore, J.F., Mulindahabi, F., Masozera, M.K., Nichols, J.D., Hines, J.E., TuRiKUnKiKo, E. et al. (2017) Are ranger patrols effective in reducing poaching-related threats within protected areas? Journal of Applied Ecology, 55, 99-107.

Nolte, C. (2016) Identifying challenges to enforcement in protected areas: empirical insights from 15 Colombian parks. Oryx, 50, 317-322.

Nyahongo, J.W., East, M.L., Mturi, F.A. \& Hofer, H. (2005) Benefits and costs of illegal grazing and hunting in the Serengeti ecosystem. Environmental Conservation, 32, 326-332.

Nyirenda, V.R. \& Сномва, C. (2012) Field foot patrol effectiveness in Kafue National Park, Zambia. Journal of Ecology and the Natural Environment, 4, 163-172.

Oduro-Ofori, E., Ocloo, E.K.A., Peprah, C. \& Effah, G. (2015) Assessing natural resource use conflicts in the Kogyae Strict Nature Reserve. Environment and Natural Resources Research, $5,56-71$.

Peres, C.A. \& Terborgh, J.W. (1995) Amazonian nature reserves: an analysis of the defensibility status of existing conservation units and design criteria for the future. Conservation Biology, 9, 34-46.

Plumptre, A.J., Fuller, R.A., Rwetsiba, A., Wanyama, F., Kujirakwinja, D., Driciru, M. et al. (2014) Efficiently targeting resources to deter illegal activities in protected areas. Journal of Applied Ecology, 51, 714-725.

Robinson, E.J. \& Lokina, R.B. (2012) Efficiency, enforcement and revenue tradeoffs in participatory forest management: an example from Tanzania. Environment and Development Economics, 17, 1-20.

SMart (Spatial Monitoring and Reporting Tool) (2021) smartconservationtools.org [accessed 11 January 2021].

Veldhuis, M.P., Ritchie, M.E., Ogutu, J.O., Morrison, T.A., BeAle, C.M., Estes, A.B. et al. (2019) Cross-boundary human impacts compromise the Serengeti-Mara ecosystem. Science, $363,1424-1428$.

WIAFE, E.D. (2016) Wildlife laws monitoring as an adaptive management tool in protected area management in Ghana: a case of Kakum Conservation Area. SpringerPlus, 5, 1440.

WiAfE, E.D. (2018) Hunted species and hunting equipment used by rainforest poachers in Ghana. Journal of Threatened Taxa, 10, 11285-11289.

WIAFE, E.D. \& АMOAH, M. (2012) The use of field patrol in monitoring of forest primates and illegal hunting activities in Kakum Conservation Area, Ghana. African Primates, 7, 238-246.

Wildife Department (1994) Kogyae Strict Nature Reserve National Park Management Plan. Wildlife Division, Accra, Ghana. 